\title{
Abandonment of timber harvesting favours European beech over silver fir: evidence from Val Tovanella Nature Reserve in the southern Dolomites (Northern Italy)
}

\author{
Tommaso Sitzia, Carlo Piazzi, Giovanni Barazzutti, Thomas Campagnaro
}

Keywords: Fagus sylvatica; Abies alba; nature conservation; forest management; land-use change; Natura 2000

\section{Abstract}

Historical data from forest management plans have the potential to shed light on changes driven by either the application or the abandonment of forestry practices. This information coupled with recent data allows temporal comparisons to be made between surveys at the same location. Here we present the temporal comparison of two forest compartments located in Val Tovanella (Oriented Nature Reserve [Riserva Naturale Orientata] and Site of Community Importance) in the south-eastern Italian Alps for which full callipering was available for two years (1957 and 2010), the first of which came from a management plan by the renowned forest ecologist Lucio Susmel (1914-2006). Both compartments currently host mixed silver fir, Norway spruce and beech stands, and have not been managed since 1948; but one was historically a high forest, whereas the other was an open wooded pasture. We aimed to reconstruct the changes in volume, number of stems and diameter classes for the two compartments by comparing species proportions and their changes over time. In both compartments, species composition changed. In general, a decrease in compositional importance of silver fir and an increase in beech were observed. Furthermore, in one compartment, Norway spruce showed a large increase. Volumetric changes confirmed such trends and highlighted a shift towards larger diameter classes. We conclude that the abandonment of traditional forest activities and, in particular, the avoidance of tending and coppicing activities are major factors favouring beech at the expense of silver fir in the study area. Traditional planning and inventory methods can help to understand long-term changes in forest structure and the effects of forestry in light of current scenarios of land-use and climate change in protected areas.

\section{Profile}

Protected area

Val Tovanella Nature

Reserve \& Natura 2000

Mountain range

Alps

Country

Italy

\section{Introduction}

Knowledge of past management practices and habitat changes are fundamental for the management of protected areas. Nevertheless, it is often difficult to obtain reliable historical data and information on past management activities (Abbitt \& Scott 2001; Chapman et al. 2006). Historical forest management plans and inventories that pre-date the use of remote sensing techniques are a source of information for retracing the evolution of the composition and structure of forests (e.g., Bürgi 1999; Hanewinkel et al. 2008; Hanewinkel et al. 2014a; Hanewinkel et al. 2014b; Klopcic et al. 2009). In many cases, such documents are the only inventories available. Combined with other historical sources, such as traditional knowledge, these documents can provide information which is otherwise impossible to obtain (Bürgi et al. 2013). At the local scale, changes in forest use could alter the evolution of tree species composition in comparison to the changes anticipated by future climatic variations (Bugmann 1997; Bugmann \& Pfister 2000; Rasche et al. 2012; Theurillat \& Guisan 2001). These historical records represent high-resolution data on tree species composition (Axelsson et al. 2002). Therefore, the validity of wide-scale projections of tree species composition change could be examined by comparing them with the historical forest plans at the local scale. Indeed, this is important for protected areas located in mountainous regions where changes in both management regimes and climate can have important consequences for biodiversity.

In the European Alps, forest management plans have been used to project forest use for both timber and non-timber products. Gimmi et al. (2008) found that in the Swiss part of the Rhône Valley, regulations in the management plans reduced the area in which traditional practices (i.e. forest litter collection and wooded pasture) could be applied, while increasing the pressure on the remaining areas. At this location, an examination of the historical management plans also revealed a shift away from Scots pine (Pinus sylvestris) to deciduous trees at lower elevations, and from Norway spruce (Picea abies, hereafter referred to as spruce) to European larch (Larix decidua) at higher elevations (Gimmi et al. 2010). In Slovenia, the structure and composition dynamics of old-growth forests have also been retraced using forest inventories and historic forest management maps (Klopcic \& Boncina 2011).

In the Alps, tree composition can be affected by several biotic and abiotic factors. Forest management has historically influenced the distribution and abun- 


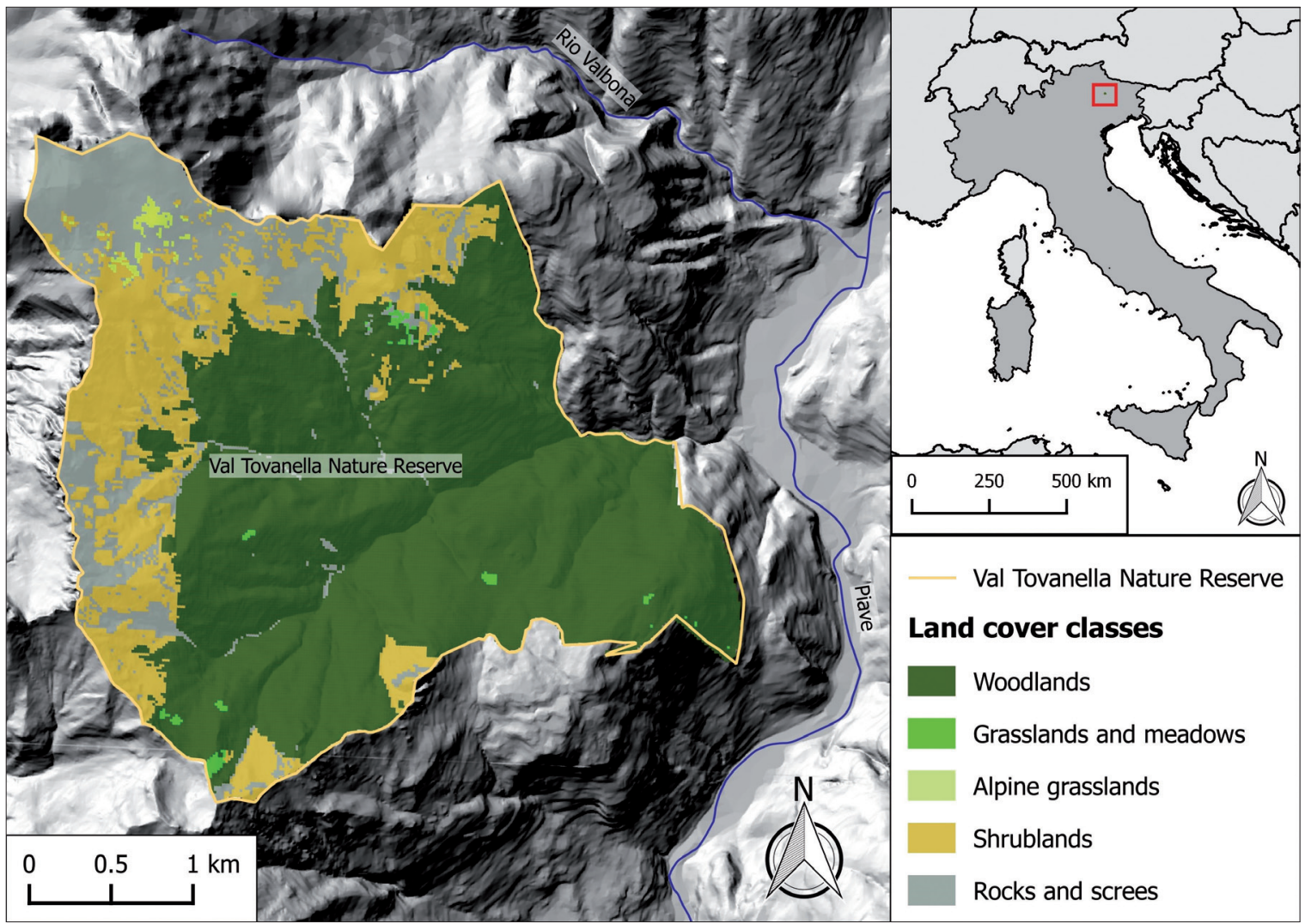

Figure 1 - Location and boundaries of the Val Tovanella Nature Reserve. Source base map: wnw.viewfinderpanoramas.org/dem3. htm

dance of tree species depending on species ecology and economic value (Conedera et al. 2017). According to the predictions of several existing species distribution models, in the Alps we should expect a future range shift for several species; for example, European beech (Fagus sylvatica, hereafter referred to as beech) and spruce are expected to retract to higher elevations while losing area at lower elevations (Zimmermann et al. 2013). Contrasting perspectives can be found in the projected and observed roles of both forest management and climate change in shaping forest composition (e.g., Gehrig-Fasel et al. 2007; Schumacher \& Bugmann 2006).

Mixed silver fir (Abies alba, hereafter referred to as fir), spruce and beech forests are among the most widespread in the Alps (Bebi et al. 2017). Some studies suggest an alternation in dominant species for this forest type (Boncina et al. 2003; Heuze et al. 2005; Klopcic et al. 2010). In many parts of this mountain range, it is not anticipated that the habitat suitability for spruce and fir will be affected by climatic changes (Zimmermann et al. 2013). However, research suggests either a recovery of fir (Theurillat \& Guisan 2001), or without proper management intervention, its further decline (Diaci et al. 2010; Ficko et al. 2011). A delayed response to climatic conditions was considered the primary explaining factor of the longterm trends and periodic decline in the growth of fir trees (Becker 1989). Intensive browsing has also been highlighted as a cause of spruce expansion over ar- eas historically dominated by fir (Klopcic et al. 2010; Schwörer et al. 2015). Furthermore, changes in forest composition may not necessarily involve responses by pioneer species (Diaci et al. 2010). Therefore, it is still unclear what compositional shifts should be expected for the future, and what the main factors are that drive the trends observed at local scale.

In this study we compared the historical and current tree species density and volume composition of two forest compartments located inside a protected area, where forest operations were halted in the late 1950s, after a long period of heavy exploitation. The renowned Italian forest ecologist Lucio Susmel (1914-2006) developed the last (and only) forest management plan for the area, in 1958. Based solely on the climatic indicators of the study region, potential forest productivity has increased since 1960 in the upper mountain belt and decreased in the valley bottom (Mariani \& Parisi 2013). The compartments are located in the limestone south-eastern Dolomites and lie between 1000 and $1300 \mathrm{~m}$ a.s.l. The current forest communities belong to the association Adenostylo glabrae-Abietetum and are a mixture of fir, spruce and beech. For our study area, we hypothesize an increase of beech over time due to the cessation of coppicing. We expect an increase in the proportion of spruce and a reduction of fir due to browsing pressure on the latter species. In addition, we expect a large absolute increase in volume and a decrease in canopy cover of pioneer tree species. 




Figure 2 - The historical compartment map of Val Tovanella (original scale 1:25000) attached to the 1958 forest plan by Lucio Susmel. Note the boundaries of the two compartments (2 and 3a) in which the historical analysis was performed. (C) L. Susmel

\section{Methods}

\section{Study area}

The Tovanella Nature Reserve $\left(46^{\circ} 18^{\prime} \mathrm{N}, 12^{\circ} 18^{\prime} \mathrm{E}\right)$ is a small, east-west oriented valley in the Dolomites, within the municipality of Ospitale di Cadore in Belluno province (Figure 1).

Glacial and fluvial erosion of the dolomitic geology formed the valley, which lies entirely within the watershed of the Rio Tovanella, a tributary of the Piave (Picco et al. 2017). A temperature increase of $0.3-0.5^{\circ} \mathrm{C} /$ decade was recorded in the study region between 1961 and 2000 (Silke et al. 2015). Despite observing slightly drier years between 1970 and 2010 compared to 1950-1970, the trend for the period 1961-2010 is not significant, and future temperature projections have a high degree of uncertainty.

In recent times, the steepness of the slopes and the remoteness of the valley have played a fundamental role in preserving this area from excessive human pressure, favouring the conservation of wild and nearly intact Alpine habitats. These conditions allowed for the creation of the Val Tovanella Oriented Biogenetic Nature Reserve in 1971. The reserve occupies an area of 1041 ha and has an altitude ranging from $500 \mathrm{~m}$ a.s.l. at the Rio Tovanella riverbed, to $2500 \mathrm{~m}$ a.s.l. at 


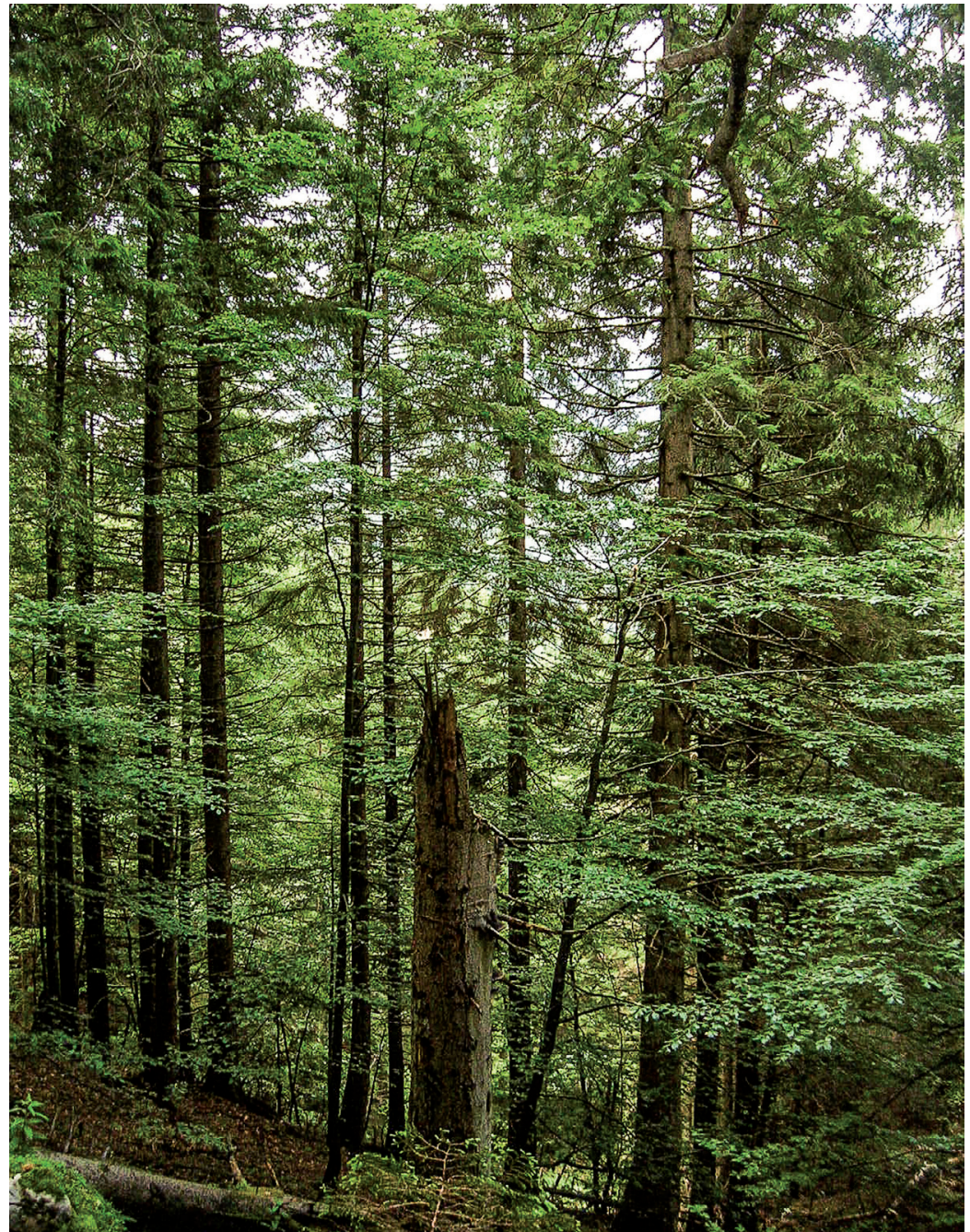

Figure 3 - Spruce snag and small-diameter beech trees in the high forest compartment (no. 2). (C) T. Sitria.

the high dolomitic cliffs of the Rocchetta-Bosconero group that surround the valley.

\section{Management history of the study area}

The forest was chosen as a case study because of its high level of wilderness and because it was analysed in depth by Susmel. In 1958, Susmel prepared the only forest management plan of the area and proposed specific silvicultural interventions (which were, however, never implemented) (Figure 2).

Until the 1950s, the Tovanella forests were the main source of income for almost the entire population of the surrounding villages, who also exploited the forests directly for their own use. For example, in 1534, 70000 beeches were cut in a single year (Di Bérenger 1863). The remains of an old system of cableways, a large number of charcoal piles distributed throughout the forest, and a few lime kilns remain as remnants of these activities (Sacchet 2007). Another important historical activity in the study area was cattle-breeding, and grazing was carried out continuously until the mid-twentieth century.
The privately-owned Val Tovanella changed hands (including those of a sawmill owner) several times during the last few centuries, until the area was bought, together with other woodlands, by the National Agency for State Forests in 1968. In 1971 the area was declared an Oriented Nature Reserve, and since December 2003 it has been part of the Val Tovanella - Bosconero - IT3230031, a Site of Community Importance within the Natura 2000 network of European protected areas.

\section{Data collection and analysis}

The forest inventory of 1957 was obtained and possible compartments to compare with the current conditions were identified. Two compartments were selected for this study (numbers 2 and 3a on Susmel's map), which display forest development processes common for the Val Tovanella Nature Reserve (Lasen et al. 2008) and for the Alpine area generally (Bebi et al. 2017). In 1957, compartment 2 was classified in the productive category as high forest, a classification which is still valid (Figure 3). By contrast, compartment 3a was classified as a wooded pasture, but it is currently covered by dense forest (Figure 4). This change represents a common process in the Alps observed over recent decades (Motta \& Dotta 1995). For these two compartments, in 2010 all stems with a diameter $>7.5 \mathrm{~cm}$ were measured in order to assess the changes in composition after 50 years of natural evolution.

Compartment 2 covers 11.38 ha that are entirely forested, whereas compartment 3 a covers 6.10 ha of which 5.78 ha are forested (current values adjusted from Susmel's). The slopes differed between the two compartments; in compartment 2, it ranged between $40 \%$ and $60 \%$, while it was around $30 \%$ in compartment 3a. Elevations are 900-1100 m a.s.l. and 1250$1300 \mathrm{~m}$ a.s.l. for compartments 2 and 3a, respectively. The soil depths and moisture content indicate more fertile conditions in the high forest (compartment 2) than in the formerly wooded pasture (compartment 3a; Susmel 1958).

Forest composition was analysed by comparing the stem numbers and the volume of each species, and the volume distribution for the diameter classes of each species. These structural parameters enable the detection of compositional changes of forests, which can be linked to forest dynamics, an approach which has been widely adopted to compare different stands (e. g., Motta \& Garbarino 2003; Sitzia et al. 2012; Vrška et al. 2009). Furthermore, these parameters enable a better understanding of possible changes in species relationships (e.g., in dominance). Therefore, in order to obtain an immediate comparison between the two years analysed, the focus was placed on changes in relative values (\%). Absolute values were used to give an overview of the condition of the compartments, in order to provide context for the observed changes in relative values, and to calculate relative changes for each species. 
When computing the volume of a forest stand, one of the most important issues is the choice of an appropriate volume table (Bettinger et al. 2009). Susmel (1958) used series 9 of the Algan volume tables. However, this information is over 50 years old and is unlikely still to be representative of the stand. Therefore, for the determination of the actual volume we used a regional system of volume tables (Del Favero 2000). To select the most appropriate volume table for each species, we compared the hypsometric curves (i.e. representing the relationship between height and diameter) of the study stands and those proposed by this regional system. Subsequently, the curves with the best fit were chosen. Each curve is identified by a numerical code and is related to various specific volumetric series representing different site fertility conditions. We used series 24 for spruce and fir, 21 for beech, and 27 for larch.

For the computation of the periodic increment, we calculated the net change by considering the initial and end volume estimates, as no trees were harvested during the period of analysis, and no information on mortality and ingrowth was available. In order to take into account the change of volume table used, we calculated the current and past volumes by using both volume tables and adopted the formula proposed in Hellrigl (1986, p. 652) to calculate the periodic increment. This method assumes that both volume tables were appropriate at the time of application, have parallel trends, and that changes in stem shape were gradual.

\section{Results}

Changes in the high forest compartment

The composition of compartment 2 has changed substantially since 1957 and the volume has almost doubled, from 240 to $465 \mathrm{~m}^{3} \mathrm{ha}^{-1}$ (Table 1). In 1957, the stand was dominated by fir in terms both of stem number and of volume, followed by spruce, which accounted for nearly $40 \%$ both in volume and number of stems (Figure $5 \mathrm{a}, \mathrm{b}$ ). Beech constituted $13 \%$ of the total number of stems, but its volume was very small.

In 2010, the relative proportions of the species had changed significantly. Fir had decreased to around just a quarter of the stems and of the total volume, whereas beech had a much larger proportion (Figure $5 \mathrm{c}$ ). The reduction in the number of fir trees can be linked to mortality without sufficient recruitment.

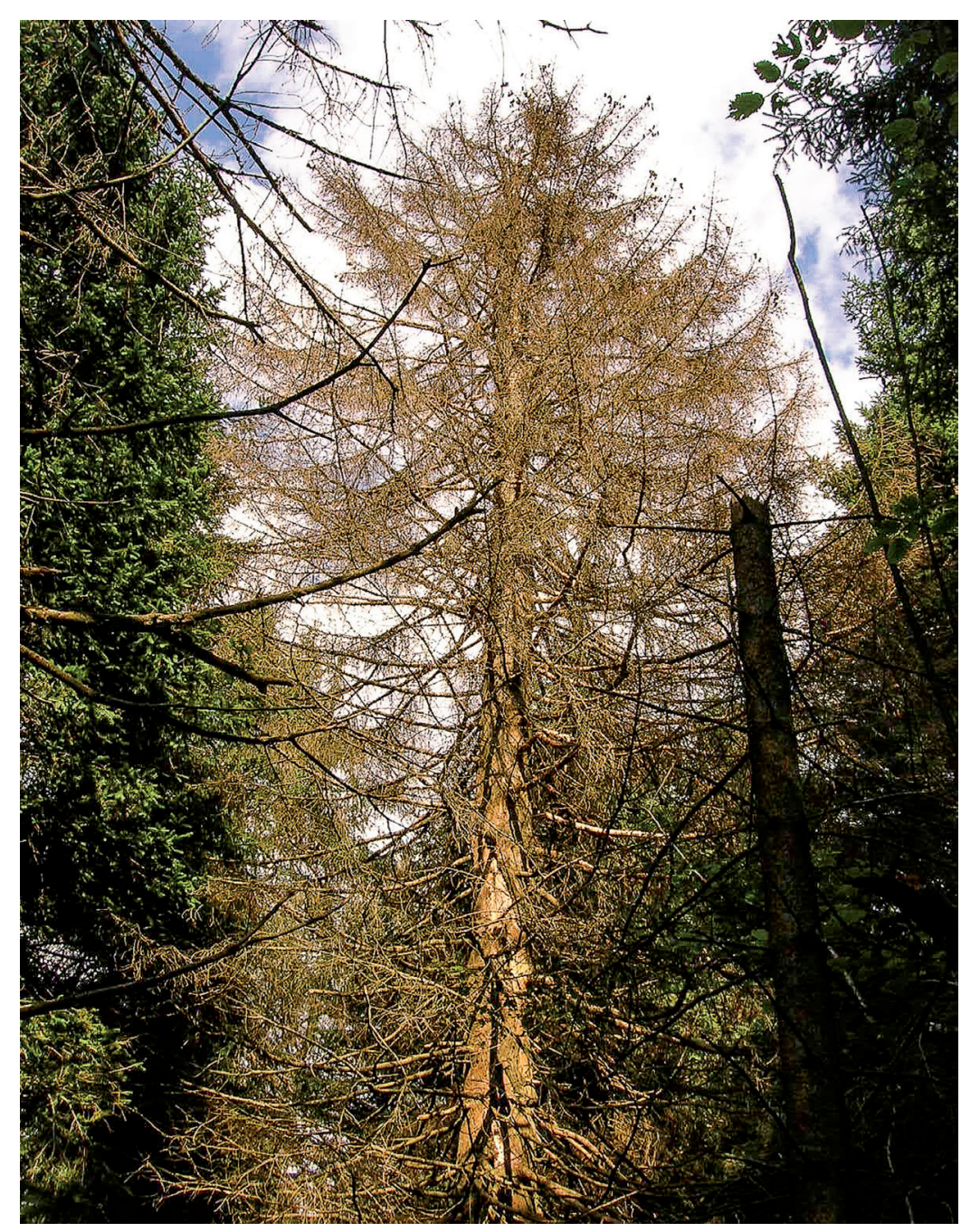

Figure 4 - Standing dead larch in the former wooded pasture compartment (no. 3a). (C) T. Sitria.

Indeed, beech showed the strongest change both in number of stems (15 times higher than in 1957) and volume (Table 1), which is mainly attributable to the high ingrowth by this species. However, the contribution of beech in terms of volume remained low, as the majority of trees had small or medium-sized diameters (Figure 6). Similarly, other species showed a substantial increase in volume. However, the most notable effect of abandonment was on spruce, which maintained its relative number of stems, but had a large increase in relative volume, accounting for more than half of the total volume in 2010 (Figures 5d and 6, Table 1). Fur-

Table 1 - Stem numbers and volume for the different species in compartment 2 (bigh forest) for 1957 and 2010, with their absolute and relative changes.

\begin{tabular}{|c|c|c|c|c|c|c|c|c|}
\hline & \multicolumn{2}{|c|}{1957} & \multicolumn{2}{|c|}{2010} & \multicolumn{2}{|c|}{ Absolute change } & \multicolumn{2}{|c|}{ Relative change[\%] } \\
\hline & stems ha-1 & $\mathrm{m}^{3} \mathrm{ha}^{-1}$ & trees $\mathrm{hq}^{-1}$ & $\mathrm{~m}^{3} \mathrm{ha}^{-1}$ & stems ha ${ }^{-1}$ & $\mathrm{~m}^{3} \mathbf{h a}^{-1}$ & stems ha-1 $^{-1}$ & $\mathrm{~m}^{3} \mathrm{ha}^{-1}$ \\
\hline Fir & 259 & 130 & 134 & 132 & -125 & +2 & -48 & +2 \\
\hline Spruce & 222 & 89 & 210 & 262 & -12 & +173 & -5 & +194 \\
\hline Beech & 10 & 11 & 159 & 40 & +149 & +29 & +1490 & +264 \\
\hline Other species & 75 & 8 & 45 & 31 & -30 & +23 & -40 & +288 \\
\hline Total & 566 & 238 & 548 & 465 & -18 & +227 & -3 & +95 \\
\hline
\end{tabular}


(a)

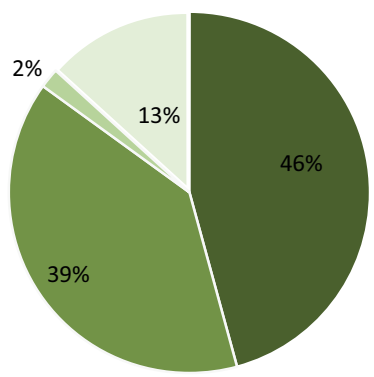

(c)

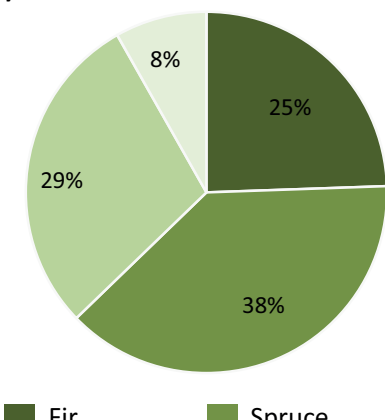

(b)

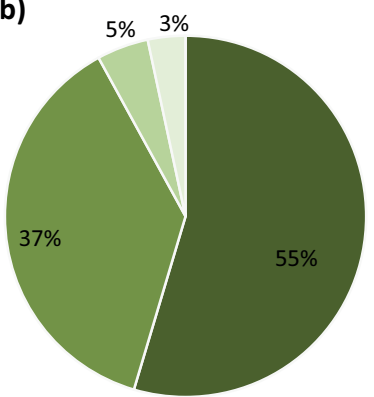

(d)

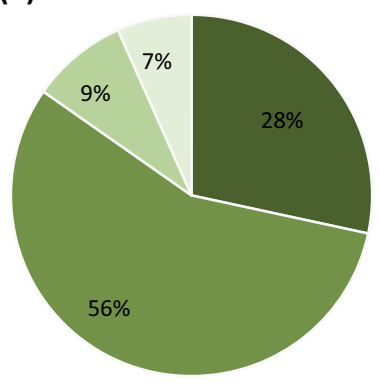

Beech
Other species
Figure 5 - Compartment 2 (bigh forest) of the Val Tovanella forest management plan: species composition (stem number percentage) in 1957 (a), and 2010 (c); species contribution (\%) to the total volume in 1957 (b), and 2010 (d). thermore, while fir had a reduction in tree numbers, volume remained similar between the two years, suggesting mortality as a main driver of this observation.

The volume distribution among diameter classes has changed radically as trees have aged (Figure 6). In 2010, the intermediate and large diameter classes (40-60 and $>60 \mathrm{~cm}$ ) comprised the largest contribution to the volume and consisted mainly of spruce and fir, while the composition of the first two classes $(<20$ and $20-40 \mathrm{~cm})$ is more balanced between different tree species. Indeed, the volume of beech increased in the small and intermediate diameter classes.

The total increment in 50 years was around $200 \mathrm{~m}^{3} \mathrm{ha}^{-1}$, corresponding to $3.9 \mathrm{~m}^{3} \mathrm{ha}^{-1} \mathrm{y}^{-1}$ and a percentage increment of $1.5 \%$.

\section{Changes in the former wooded pasture compartment}

During 50 years of abandonment, this compartment underwent radical changes, mainly as a consequence of the cessation of cattle grazing. As highlighted by Susmel, in 1957 the area had the typical characteristics of a wooded pasture, with a low-density stand characterized by scattered or small-group distribution. Trees were heavily tapered, with large crown dimensions (up to $400 \mathrm{~m}^{2}$ crown horizontal area); spruce dominated the stand in both number of stems and volume (Figure 7). As frequently occurs in wooded pastures, due to its light crown larch (which is the main component of other category) was favoured and accounted for nearly $15 \%$ in number of stems and volume. In contrast, beech and fir comprised only a marginal part of the composition.

The most visible change in composition was the increase of beech present in 2010, with a relatively large number of stems (411 stems ha-1, 64\%) of small diameter $(10-15 \mathrm{~cm})$, which are primarily of vegetative origin, growing from old stumps. Spruce still represented the largest part of the volume, but the number of individuals had decreased massively and accounted for less than one third of the trees. The larch volume had halved, while the amount of fir remained marginal. Indeed, changes in number of stems and volume are different between species (Table 2).

Total volume increased from 100 to $374 \mathrm{~m}^{3} \mathrm{ha}^{-1}$, with beech having the highest increase (18 times greater).

Table 2 - Stem numbers and volume for the different species in compartment 3 a fformer wooded pasture) for 1957 and 2010, with their absolute and relative changes.

\begin{tabular}{|c|c|c|c|c|c|c|c|c|}
\hline & \multicolumn{2}{|l|}{1957} & \multicolumn{2}{|l|}{2010} & \multicolumn{2}{|c|}{ Absolute change } & \multicolumn{2}{|c|}{ Relative change [\%] } \\
\hline & stems ha-1 & $\mathrm{m}^{3} \mathrm{ha}^{-1}$ & stems ha ha $^{-1}$ & $\mathbf{m}^{3} \mathbf{h a}^{-1}$ & stems ha ${ }^{-1}$ & $\mathrm{~m}^{3} \mathrm{hq}^{-1}$ & stems ha-1 & $\mathrm{m}^{3} \mathrm{hq}^{-1}$ \\
\hline Fir & 15 & 3 & 15 & 12 & 0 & +9 & 0 & +300 \\
\hline Spruce & 183 & 78 & 174 & 235 & -9 & +157 & -5 & +201 \\
\hline Beech & 35 & 5 & 411 & 96 & +376 & +91 & +1074 & +1820 \\
\hline Other species & 34 & 14 & 43 & 31 & +9 & +17 & +26 & +121 \\
\hline Total & 267 & 100 & 643 & 374 & +376 & +274 & +141 & +274 \\
\hline
\end{tabular}


Fir volume also increased, but not the number of stems, and similar changes were observed for spruce. The periodic increment after half a century was around $258 \mathrm{~m}^{3} \mathrm{ha}^{-1}$, corresponding to $4.9 \mathrm{~m}^{3} \mathrm{ha}^{-1} \mathrm{y}^{-1}$, a percentage increment of $4.3 \%$.

If we compare the volume distribution among species and diameter classes between 1957 and 2010 (Figure 8), the highest volume in both cases was of trees belonging to the intermediate classes, while the contribution of beech increased in 2010. The composition and volume proportions of the largest class $(>60 \mathrm{~cm})$, which in the past was absent, mirror the $40-60 \mathrm{~cm}$ class in 1957, and these trees were now dominant.

\section{Discussion}

Earlier studies have documented the dynamics that characterize mixed forests of fir, spruce and beech (e. g., Šamonil \& Vrška 2007; Vrška et al. 2009). These species have different ecological characteristics and form communities that are often conditioned by a multiplicity of factors. This complexity makes it difficult to identify the factors playing the greatest role in shaping these communities. In general, our study showed that management abandonment was most favourable to beech, and to a lesser extent spruce, while fir did not react positively to this management change. Furthermore, the information from the historical management plan was fundamental for understanding and interpreting the current forest biodiversity conditions (Trentanovi et al. 2017).

An increase in growing stock during recent decades has been observed for Alpine forests (Ballmer et al. 2014; Bürgi 1999; Klopcic \& Boncina 2011; Klopcic et al. 2010). In our case, the strong increase in volume
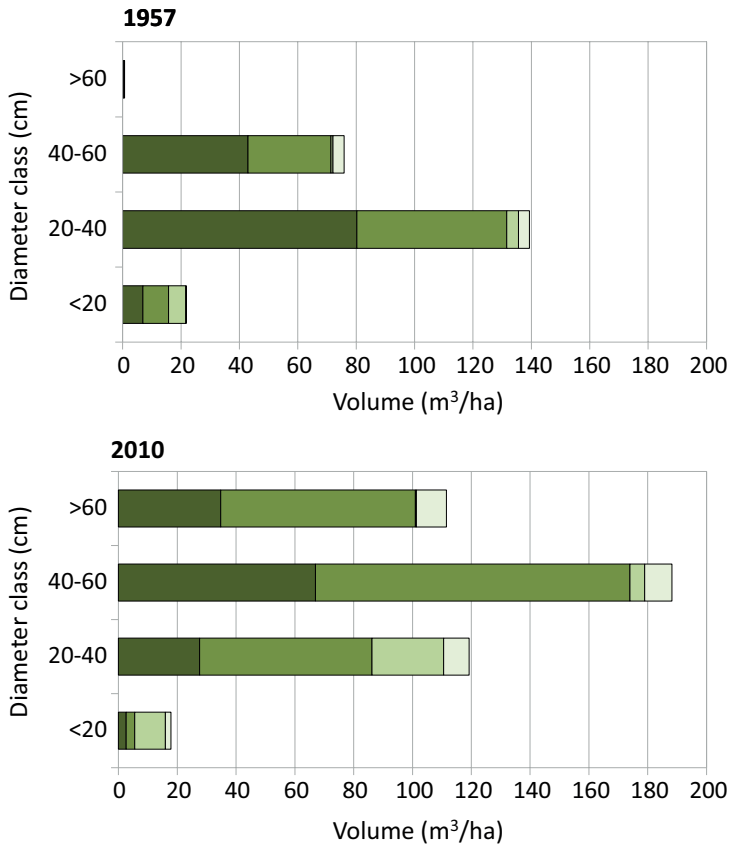

Fir

Other species

Figure 6 - Species contribution to volume per hectare, for 1957 and 2010, for diameter classes in compartment 2 (bigh forest) of the Val Tovanella forest management plan.

within the high forest compartment can be explained by analysing the past forest conditions. According to Susmel (1958), the greatest problem affecting the stand was the excessively low volume, due mainly to the almost total lack of plants of large dimensions and the scarce presence of trees with intermediate diameters. One of the causes of the low volume was "the wrong cuttings made in the period 1943-1947, which removed all the trees with the best characteristics [...], and now (a)

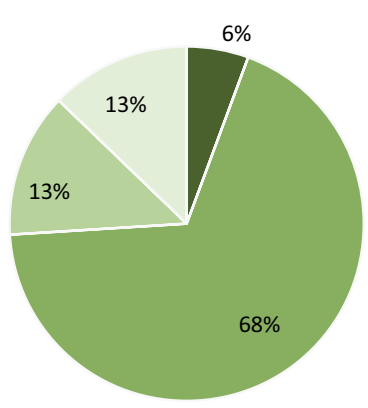

(c)

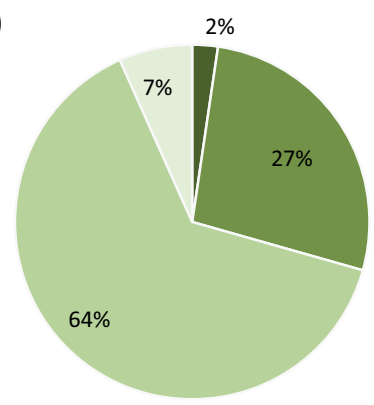

Fir

Spruce (b)

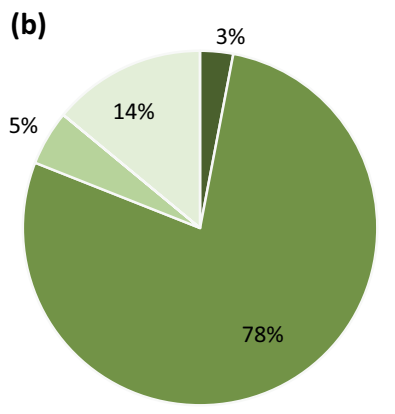

(d)

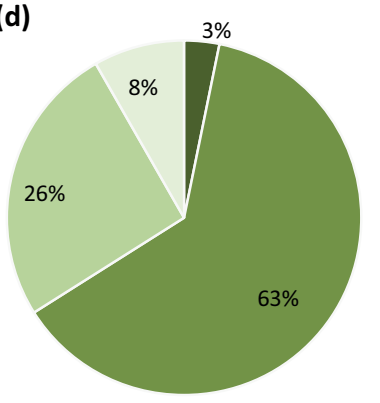

Beech
Figure 7 - Compartment $3 a$ (former wooded pasture) of the Val Tovanella forest management plan: composition (trees/ha) in 1957 (a), and 2010 (c); species contribution to volume in 1957 (b), and 2010 (d). 

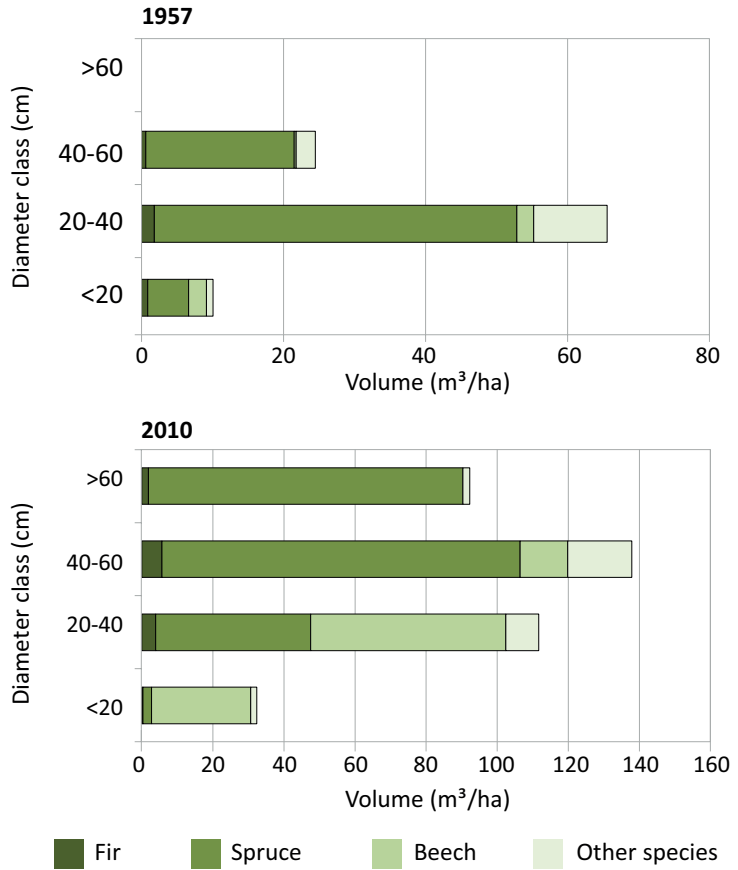

Beech

Other species

Figure 8-Species contribution to volume per hectare, for 1957 and 2010, for diameter classes in compartment 3 a (former wooded pasture) of the Val Tovanella forest management plan.

the dominant layer is composed mainly of small, often defective individuals, with low growth and mediocre vegetative status" (Susmel 1958). The observed increment value for the period 1957-2010 is lower than that indicated by Del Favero (2000) $\left(5.6 \mathrm{~m}^{3} \mathrm{ha}^{-1} \mathrm{y}^{-1}\right)$ as being optimal for multi-layered fir woods in the study region. The increase in total volume, which was also observed in the wooded pasture compartment, is still relatively low when compared to other mixed forests which have been abandoned for longer periods of time, indicating that there is still growing space available in both compartments.

In 1957, in the wooded pasture compartment the pasture was already degraded and the forest was "spontaneously recovering its original supremacy", as reported by Susmel (1958). This natural succession continued; currently the entire compartment is covered with forest and only a few small gaps interrupt the continuous canopy cover. Because of the ecology of larch and spruce, canopy closure is likely to be the main reason for the relative stability in the number of larch trees and the decrease in spruce, in comparison to the more shade-tolerant beech. The increase in volume of larch, spruce and fir is probably due to the increase in volume of those trees that were already present in 1957.

In general, a decline in fir has been observed in Europe, and a number of different explanations have been proposed. The species' share in the growing stock seems to have increased in the western Alps, but decreased in the eastern part (Bebi et al. 2017). A cyclical model in which fir and beech species alternate at the small scale and with precise regeneration periods has been theorized for the Carpathian fir-beech stands (Saniga in Vrška et al. 2009). Nevertheless, in disturbed forests, a linear trend where fir is replaced by beech can be explained by the effects of past grazing and litter collection (Šamonil \& Vrška 2007; Vrška et al. 2009).

A possible negative effect related to climate change is low growth rate due to recurrent drought during the growing season. However, this effect can vary depending on microclimatic conditions (Rolland et al. 1999). A recent study suggests that, based on the observed increase in the upper limit of fir (an increase of about $300 \mathrm{~m}$ in elevation) because of reduced human pressure, future land-use changes in the Alps are likely to play a more important role than climate change in the distribution of fir communities (Chauchard et al. 2010). In agreement with Chauchard et al. (2010), Ficko et al. (2011) found that the effects of climate change appear to be masked by other local factors, such as excessive damage to the natural regeneration of fir caused by wild ungulates. This fear is supported by the high density of red deer in the study region, a density which continues to increase (Ramanzin \& Sommavilla 2009). In this respect, it is important to consider that in a nearby forest (Cansiglio), the density of red deer has reached 9-10 individuals per $100 \mathrm{ha}$, and firs have been heavily browsed and debarked much more than beech and spruce (Caudullo et al. 2003). Similar densities were highlighted as potentially threatening for fir regeneration by Diaci et al. (2010). It is likely that this pressure has resulted in the limited ingrowth for fir at this location, as this species should normally regenerate successfully under shady conditions.

The trends observed in this study are mostly related to the past history of silvicultural and pastoral use. The proportion of beech increased in both the formerly high forest and wooded pasture compartments. This increase is driven largely by the substantial ingrowth of small stems. The drastic reduction of fir suggests that the species is gradually being replaced by beech and spruce in terms of compositional importance. Ficko (2011) reported that the increase of fir share in the large-diameter classes and its decrease in the medium- and small-diameter classes were a sign of a lack of recruitment. In our study area, it is possible that the older fir trees were not producing enough seeds able to germinate and develop, and that this, together with the effect of browsing, prevented the establishment of new trees.

In 1958, Susmel predicted most of the current forests conditions. He attributed the low proportion of beech at that time to the long history of beech suppression by past foresters. Moreover, he predicted a strong recovery thanks to the abundance of individuals originating from seed and from sprouting. He also described the presence of an excessively high number of mature firs that showed signs of early aging, at around 80-100 years. Susmel predicted that without intervention an excessive increase of the volume would occur, with an inadequate diameter-class distribution. It is noteworthy that in nearby forests, where 
forest management is still active, fir still constitutes a high proportion in tree density and volume (Sitzia et al. 2012). Therefore, in contrast with some previous findings (e.g. Motta \& Garbarino 2003), we suggest that the absence of intervention may lead to a further decline of fir, at least in the medium term and at the elevations studied. Furthermore, the absence of management and changes in tree composition for these forests could have consequences on biodiversity, such as in the richness and diversity of several animal and plant taxa (Nascimbene et al. 2013; Sitzia et al. 2017; Sitzia et al. 2015), and could lead to an increase in forest cover at the expense of grasslands and shrublands (Campagnaro et al. 2017).

\section{Conclusions}

The comparison in composition of two forest compartments between 1957 and 2010 gave us the opportunity to understand changes over time due to the abandonment of silvicultural and grazing activities. This involved investigating the changes that a forest undergoes during the process of wilderness recovery. The study found a relative decrease in fir proportion, while beech and spruce tended to increase, showing that changes in stem number and volume were unevenly distributed between tree species. This change in the volumetric proportions among the main species raises questions about long-term fir conservation in these forests.

We conclude that forest management abandonment has played a major role in shaping the changes observed, although it is likely that other factors not considered here directly have also been drivers of change (e.g. ungulate pressure and climatic factors). Finally, our study confirmed (e.g. Diaci et al. 2010) that traditional inventory methods are still an important tool for long-term comparisons of forest stands, even in an era of strong technological innovation (e.g. remote-sensing techniques, Pirotti et al. 2012).

\section{Acknowledgements}

This project was supported by the Italian Ministry of Agricultural, Food and Forestry Policies, State Forestry Corps (Project Managers: Antonio Andrighetti and Dario Campedel) within the framework of the research agreement No. 767/2008 with the Università degli Studi di Padova (PI: T. Sitzia) and by a PhD grant to T. Campagnaro from the Università degli Studi di Padova, Dept. Land, Environment, Agriculture and Forestry. The authors express their thanks to Andrea Sgarbossa, Veronica Scapin, and Thomas Zinato for their assistance in data collection and to Monica Sommacal for her support coordinating the work. We also thank two anonymous reviewers for commenting and advising on a previous version of this paper; and Daniel Hawtree and Mary Rigby for language revision.

\section{References}

Abbitt, R.J.F. \& M.J. Scott 2001. Examining differences between recovered and declining endangered species. Conservation Biology 15: 1274-1284.

Axelsson, A.-L., L. Östlund \& E. Hellberg 2002. Changes in mixed deciduous forests of boreal Sweden 1866-1999 based on interpretation of historical records. Landscape Ecology 17: 403-418.

Ballmer, I., C. Heiri, R. Brücker, R. Tinner, J. Wunder \& P. Brang 2014. Auswertung der Vollkluppierung 2012 im Naturwaldreservat Aletschwald. Birmensdorf. [In German]

Bebi, P., R. Seidl, R. Motta, M. Fuhr, D. Firm, F. Krumm, M. Conedera, C. Ginzler, T. Wohlgemuth \& D. Kulakowski 2017. Changes of forest cover and disturbance regimes in the mountain forests of the Alps. Forest Ecology and Management 388: 43-56.

Becker, M. 1989. The role of climate on present and past vitality of silver fir forests in the Vosges mountains of northeastern France. Canadian Journal of Forest Research 19: 1110-1117.

Bettinger, P., K. Boston, J.P. Siry \& D.L. Grebner 2009. Forest management and planning. Amsterdam.

Boncina, A., F. Gaspersic \& J. Diaci 2003. Longterm changes in tree species composition in the Dinaric mountain forests of Slovenia. The Forestry Chronicle 79: 227-232.

Bugmann, H. 1997. Sensitivity of forests in the European Alps to future climatic change. Climate Research 8: 35-44.

Bugmann, H. \& C. Pfister 2000. Impacts of interannual climate variability on past and future forest composition. Regional Environmental Change 1: 112-125.

Bürgi, M. 1999. A case study of forest change in the Swiss lowlands. Landscape Ecology 14: 567-576.

Bürgi, M., U. Gimmi \& M. Stuber 2013. Assessing traditional knowledge on forest uses to understand forest ecosystem dynamics. Forest Ecology and Management 289: 115-122.

Campagnaro, T., L. Frate, M.L. Carranza \& T. Sitzia 2017. Multi-scale analysis of alpine landscapes with different intensities of abandonment reveals similar spatial pattern changes: Implications for habitat conservation. Ecological Indicators 74: 147-159.

Caudullo, G., R. De Battisti, C. Colpi, C. Vazzola \& F. Da Ronch 2003. Ungulate damage and silviculture in the Cansiglio forest (Veneto Prealps, NE Italy). Journal for Nature Conservation 10: 233-241.

Chapman, R.A., E. Heitzman \& M.G. Shelton 2006. Long-term changes in forest structure and species composition of an upland oak forest in Arkansas. Forest Ecology and Management 236: 85-92.

Chauchard, S., F. Beilhe, N. Denis \& C. Carcaillet 2010. An increase in the upper tree-limit of silver fir (Abies alba Mill.) in the Alps since the mid-20th century: A land-use change phenomenon. Forest Ecology and Management 259: 140-1415. 
Conedera, M., D. Colombaroli, W. Tinner, P. Krebs \& C. Whitlock 2017. Insights about past forest dynamics as a tool for present and future forest management in Switzerland. Forest Ecology and Management 388: 100-112.

Del Favero, R. 2000. Biodiversità e indicatori nei tipi forestali del Veneto. Venezia. [In Italian]

Di Bérenger, A. 1863. Saggio storico della legislazione veneta forestale dal sec. VII al XIX. Venezia. [In Italian]

Diaci, J., D. Rozenbergar \& A. Boncina 2010. Stand dynamics of Dinaric old-growth forest in Slovenia: Are indirect human influences relevant? Plant Biosystems 144: 194-201.

Ficko, A., A. Poljanec \& A. Boncina 2011. Do changes in spatial distribution, structure and abundance of silver fir (Abies alba Mill.) indicate its decline? Forest Ecology and Management 261: 844-854.

Gehrig-Fasel, J., A. Guisan \& N.E. Zimmermann 2007. Tree line shifts in the Swiss Alps: climate change or land abandonment? Journal of Vegetation Science 18.

Gimmi, U., M. Burgi \& M. Stuber 2008. Reconstructing anthropogenic disturbance regimes in forest ecosystems: A case study from the Swiss Rhone Valley. Ecosystems 11: 113-124.

Gimmi, U., T. Wohlgemuth, A. Rigling, C.W. Hoffmann \& M. Burgi 2010. Land-use and climate change effects in forest compositional trajectories in a dry Central-Alpine valley. Annals of Forest Science 67: 701.

Hanewinkel, M., J. Breidenbach, T. Neeff \& E. Kublin 2008. Seventy-seven years of natural disturbances in a mountain forest area-the influence of storm, snow, and insect damage analysed with a longterm time series. Canadian Journal of Forest Research 38: 2249-2261.

Hanewinkel, M., F. Frutig \& R. Lemm 2014a. Economic performance of uneven-aged forests analysed with annuities. Forestry 87: 49-60.

Hanewinkel, M., T. Kuhn, H. Bugmann, A. Lanz \& P. Brang 2014b. Vulnerability of uneven-aged forests to storm damage. Forestry 87: 525-534.

Hellrigl, B. 1986. Il rilevamento dendro-cronoauxometrico. In: Hellrigl, B. (ed.), Nuove metodologie nella elaborazione dei piani di assestamento dei boschi: 399-704. Bologna. [In Italian]

Heuze, P., A. Schnitzler \& F. Klein 2005. Consequences of increased deer browsing winter on silver fir and spruce regeneration in the Southern Vosges mountains: Implications for forest management. $A n$ nals of Forest Science 62: 175-181.

Klopcic, M. \& A. Boncina 2011. Stand dynamics of silver fir (Abies alba Mill.)-European beech (Fagus sylvatica L.) forests during the past century: a decline of silver fir? Forestry 84: 259-271.

Klopcic, M., K. Jerina \& A. Boncina 2010. Longterm changes of structure and tree species composition in Dinaric uneven-aged forests: are red deer an important factor? European Journal of Forest Research 129: 277-288.
Klopcic, M., A. Poljanec, A. Gartner \& A. Boncina 2009. Factors related to natural disturbances in mountain Norway spruce (Picea abies) forests in the Julian Alps. Écoscience 16: 48-57.

Lasen, C., A. Scariot \& T. Sitzia 2008. Natura 2000 Habitats map, forest type and vegetation outline of Val Tovanella Nature Reserve. In: Hardersen, S., F. Mason, F. Viola, D. Campedel, C. Lasen \& M. Cassol (eds.), Research on the natural heritage of the reserves Vincheto di Celarda and Val Tovanella (Belluno province, Italy). Conservation of two protected areas in the context of a Life Project. Quaderni Conservazione Habitat 5: 325-334. Verona. [In Italian]

Mariani, L. \& S.G. Parisi 2013. Indice di Paterson. In: Barbi, A., A. Cagnati, G. Cola, F. Checchetto, A. Chiaudani, A. Crepaz, I. Delillo, L. Mariani, G. Marigo, P. Meneghin, S.G. Parsi, F. Rech, B. Renon \& T. Robert-Luciani, Atlante climatico del Veneto. Precipitazioni Basi informative per l'analisi delle correlazioni tra cambiamenti climatici e dinamiche forestali nel Veneto: 225-231. Venezia. [In Italian]

Motta, R. \& A. Dotta 1995. Les mélézeins des Alpes Occidentales: un paysage à defendre. Revue Forestiere Francaise 47: 329-342.

Motta, R. \& F. Garbarino 2003. Stand history and its consequences for the present and future dynamic in two silver fir (Abies alba Mill.) stands in the high Pesio Valley (Piedmont, Italy). Annals of Forest Science 60: 361-370.

Nascimbene, J., M. Dainese \& T. Sitzia 2013. Contrasting responses of epiphytic and dead wood-dwelling lichen diversity to forest management abandonment in silver fir mature woodlands. Forest Ecology and Management 289: 325-332.

Picco, L., F. Comiti, L. Mao, A. Tonon \& M.A. Lenzi 2017. Medium and short term riparian vegetation, island and channel evolution in response to human pressure in a regulated gravel bed river (Piave River, Italy). Catena 149: 760-769.

Pirotti, F., S. Grigolato, E. Lingua, T. Sitzia \& P. Tarolli 2012. Laser scanner applications in forest and environmental sciences. Italian Journal of Remote Sensing 44: 109-123.

Ramanzin, M. \& G. Sommavilla 2009. Piano Faunistico Venatorio. Aggiornamento 2009-2014. Belluno.

Rasche, L., L. Fahse, A. Zingg \& H. Bugmann 2012. Enhancing gap model accuracy by modeling dynamic height growth and dynamic maximum tree height. Ecological Modelling 232: 133-143.

Rolland, C., R. Michalet, C. Desplanque, A. Petetin \& S. Aime 1999. Ecological requirements of Abies alba in the French Alps derived from dendro-ecological analysis. Journal of Vegetation Science 10: 297-306.

Sacchet, A. 2007. Vicende storiche ed aspetti etnografici. In: Dal Cortivo, M., E. Gatti, J. Nascimbene \& M. Sommacal (eds.), Guida alla riserva naturale orientata Val Tovanella: 19-33. Belluno. [In Italian]

Šamonil, P. \& T. Vrška 2007. Trends and cyclical changes in natural fir-beech forests at the north- 
western edge of the Carpathians. Folia Geobotanica 42: 337-361.

Schumacher, S. \& H. Bugmann 2006. The relative importance of climatic effects, wildfires and management for future forest landscape dynamics in the Swiss Alps. Global Change Biology 12: 1435-1450.

Schwörer, C., D. Colombaroli, P. Kaltenrieder, F. Rey \& W. Tinner 2015. Early human impact (5000 3000 BC) affects mountain forest dynamics in the Alps. Journal of Ecology 103: 281-295.

Silke, A., B. Chimani, S. Drechsel, K. Haslinger, J. Hiebl, V. Meyer, G. Resch, J. Rudolph, J. Vergeiner, C. Zingerle \& G. Marigo 2015. Il clima del Tirolo - Alto Adige - Bellunese. Bolzano and Venezia. [In Italian]

Sitzia, T., T. Campagnaro, M. Dainese, M. Cassol, M. Dal Cortivo, E. Gatti, F. Padovan, M. Sommacal \& J. Nascimbene 2017. Contrasting multi-taxa diversity patterns between abandoned and non-intensively managed forests in the southern Dolomites. iForest 10: 845-850.

Sitzia, T., T. Campagnaro, E. Gatti, M. Sommacal \& D.J. Kotze 2015. Wildlife conservation through forestry abandonment: responses of beetle communities to habitat change in the Eastern Alps. European Journal of Forest Research 134: 511-524.

Sitzia, T., G. Trentanovi, M. Dainese, G. Gobbo, E. Lingua \& M. Sommacal 2012. Stand structure and plant species diversity in managed and abandoned silver fir mature woodlands. Forest Ecology and Management 270: 232-238.

Susmel, L. 1958. Piano di riordinamento della proprietà silvo-pastorale Costantini in Val Tovanella (1958-1967). Firenze. [In Italian]

Theurillat, J.P. \& A. Guisan 2001. Potential impact of climate change on vegetation in the European Alps: A review. Climatic Change 50: 77-109.

Trentanovi, G., T. Campagnaro, A. Rizzi \& T. Sitzia 2017. Synergies of planning for forests and planning for Natura 2000: Evidences and prospects from northern Italy. Journal for Nature Conservation. DOI: 10.1016/j.jnc.2017.07.006

Vrška, T., D. Adam, L. Hort, T. Kolář \& D. Janík 2009. European beech (Fagus sylvatica L.) and silver fir (Abies alba Mill.) rotation in the Carpathians - A devel- opmental cycle or a linear trend induced by man? Forest Ecology and Management 258: 347-356.

Zimmermann, N.E., R. Jandl, M. Hanewinkel, G. Kunstler, C. Kölling, P. Gasparini, A. Breznikar, E.S. Meier, S. Normand, U. Ulmer, T. Gschwandtner, H. Veit, M. Naumann, W. Falk, K. Mellert, M. Rizzo, M. Skudnik \& A. Psomas 2013. Potential future ranges of tree species in the Alps. In: Cerbu, G.A., M. Hanewinkel, G. Gerosa \& R. Jandl (eds.), Management strategies to adapt alpine space forests to climate change risks: 37-48. Rijeka.

\section{Authors}

\section{Tommaso Sitzia}

is professor of forest management at the Università degli Studi di Padova. His main research interests are forest management and planning, landscape ecology, biological invasions and protected areas. E-mail: tommaso.sitzia@unipd.it

\section{Carlo Piazzi}

holds a MSc in Forestry and Environmental Science from, the Università degli Studi di Padova. His research interests include forest management, landscape conservation and habitat ecology. E-mail: carlo. piazzi@studenti.unipd.it

\section{Giovanni Barazzutti}

holds a MSc in Forestry and Environmental Science from the Università degli Studi di Padova. His research interests are forest management and biodiversity conservation. E-mail: gio.barazzutti@libero.it

Thomas Campagnaro - corresponding author is a research fellow at the Università degli Studi di Padova. His research interests are habitat management, biological invasions, urban forestry and landscape ecology. E-mail: thomas.campagnaro@unipd.it

1 Università degli Studi di Padova, Department of Land, Environment, Agriculture and Forestry, Viale dell'Università 16, 35020 Legnaro (PD), Italy. 